\title{
An Early Umayyad Papyrus Invitation for the Hajj
}

\author{
Petra M. Sijpesteijn, Leiden University ${ }^{1}$
}

\section{Introduction $^{2}$}

Some time between 86/705 and 99/717, Sahl b. 'Abd al-'Azīz wrote a letter to 'Uqba b. Muslim, conveying a message from the amī al-mu'minin, the caliph. The caliph, Sahl wrote, had announced that the time had come to make the pilgrimage, the bajj, and had exhorted all Muslims to do so. Sahl urged 'Uqba, if he was able, to join him on the pilgrimage and to bring Sahl's camels with him, bearing the costs for one camel himself.

\footnotetext{
${ }^{1}$ I would like to thank Fred Donner and Paul Cobb who started to work on this papyrus independently and then generously shared their findings with me. I should also thank Patricia Crone, Wadad al-Kadi, Gerald Hawting and Eli Alshech for their comments on earlier drafts of this paper. The paper was first presented at the Middle Eastern Studies Association meeting in 2002, at the Institut Français d'Archéologie Orientale du Caire in 2007, and at the Institut für Alte Geschichte und Altertumskunde, Papyrologie und Epigraphik in Vienna in 2013. I would like to thank the participants of those three events for their remarks. Any errors that remain are, of course, entirely my own.

${ }^{2}$ In this article, all dates are given as either AH/AD or simply $\mathrm{AD}$, and the following abbreviations are used: Chrest. Khoury $\mathrm{I}=$ A. Grohmann and R. G. Khoury, ed., Chrestomathie de papyrologie arabe. Documents relatifs à la vie privé sociale et administrative dans les premiers siècles islamiques. Handbuch der Orientalistik. Ergänzungsband 2, Zweiter Halbband (Leiden, 1993); CPR VIII = P. J. Sijpesteijn and K. A. Worp, ed., Griechische Texte V. Corpus Papyrorum Raineri VIII (Vienna, 1983); CPR XXII = F. Morelli, ed., Griechische Texte XV, Documenti greci per la fiscalità e la amministrazione dell'Egitto arabo. Corpus Papyrorum Raineri
}

This letter, written on papyrus, was found in Egypt, where both men were probably living at the time it was sent, and it is now housed in the Oriental Institute Museum collection at the University of Chicago. It is the earliest documentary evidence for the bajj currently known, and offers important insight into the significance and meaning of the Muslim pilgrimage at the time of its composition. ${ }^{3}$

XXII (Vienna, 2001); EI2 = Encyclopaedia of Islam, new edition, (Leiden, 1954-2004); Hopkins = S. Hopkins, Studies in the Grammar of Early Arabic, Based upon Papyri Datable to Before 300 A.H./912 A.D. London Oriental Series 37 (Oxford, 1984); P. Apoll. = R. Rémondon, ed., Papyrus grecs d'Apollônos Anô. Documents de fouilles de l'Institut Français d'Archéologie Orientale du Caire 19 (Cairo, 1953); P.Berl.Arab. II = W. Diem, ed., Arabische Briefe des 7. bis 13. Jahrbunderts aus den Staatlichen Museen zu Berlin. Documenta Arabica Antiqua 4 (Wiesbaden, 1997); P.Cair. Arab. = A. Grohmann, ed., Arabic Papyri in the Egyptian Library vols. 1-6 (Cairo, 1934); P.Heid.Arab. I = C. H. Becker, ed., Papyri Schott-Reinhardt I. Veröffentlichungen aus der Heidelberger Papyrussammlung 3 (Heidelberg, 1906); P.Heid.Arab. II = W. Diem, ed., Arabische Briefe auf Papyrus und Papier aus der Heidelberger Papyrus-Sammlung (Wiesbaden, 1991); P.Khalili I = G. Khan, ed., Arabic Papyri: Selected Material from the Khalili Collection. Studies in the Khalili Collection I (London, 1992); P.Lond. IV = H. I. Bell, ed., The Aphrodito Papyri, (London, 1910); P.Qurra = N. Abbott, ed., The Kurrah Papyri from Aphrodito in the Oriental Institute. Studies in Ancient Oriental Civilization 15 (Chicago, 1938).

${ }^{3}$ An unpublished second/eighth-century papyrus AP 1626r kept in the Papyrussammlung of the Austrian National Library mentions qabla al-adha as an indication of time, presumably referring to ' $\bar{c} d a l-a d h \bar{a}$, the feast of sacrifice commemorating the slaughtering

[JNES 73 no. 2 (2014)] @ 2014 by The University of Chicago. All rights reserved. 022-2968-2014/7302-009 \$10.00. 

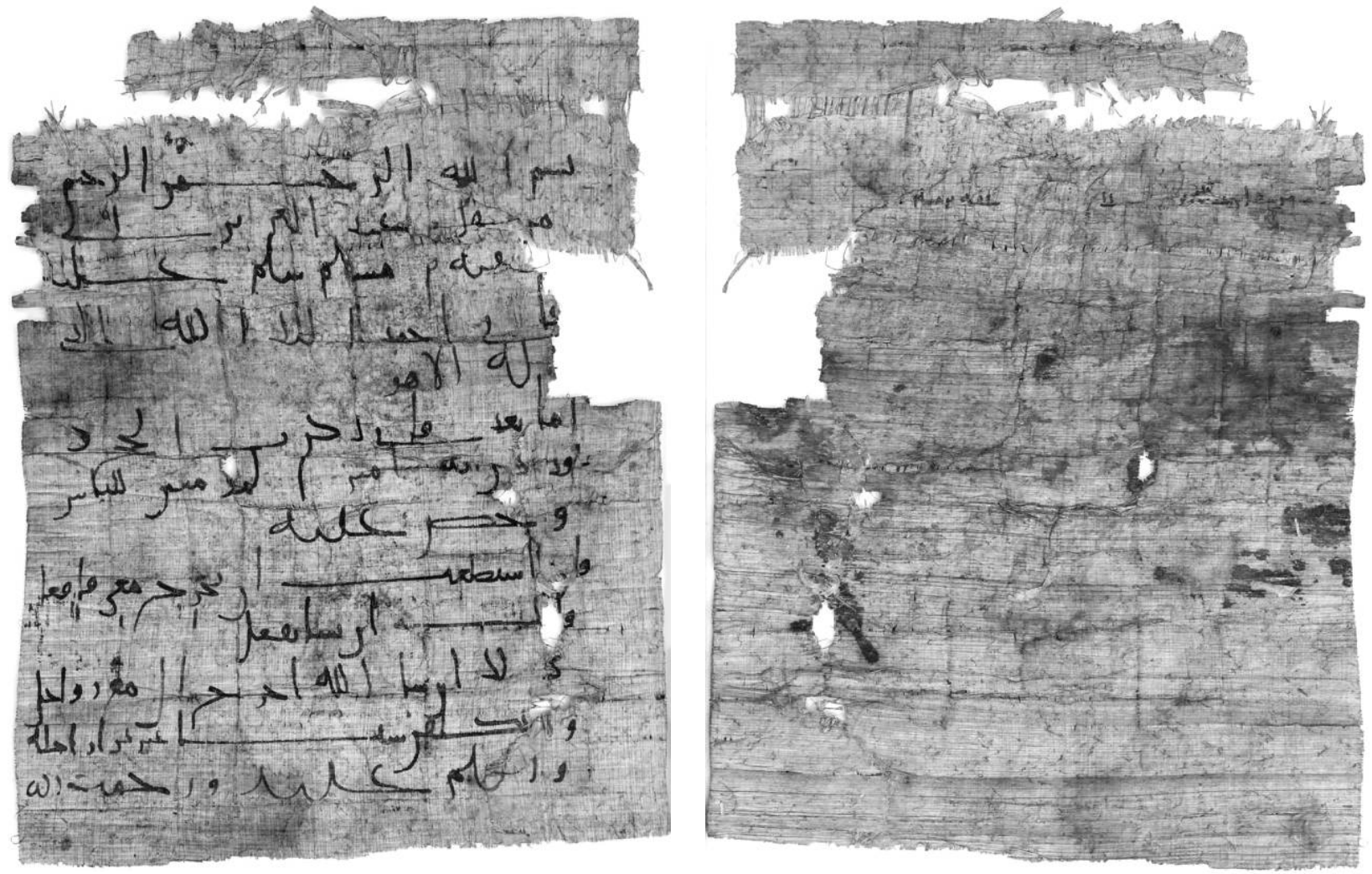

Figure 1-OI 17653, Sides A (Letter) and B (Address). Courtesy of the Oriental Institute Museum, the University of Chicago. Photo: Anna R. Ressman.

\section{Papyrus OI 17653: Edition and Discussion ${ }^{4}$}

Papyrus OI 17653 (Fig. 1): $24 \mathrm{~cm} \mathrm{H} \mathrm{x} 20.5 \mathrm{~cm} \mathrm{~W} \mathrm{(ca.}$ 86-99/705-717) is a middle brown papyrus, written in black ink with a thin pen perpendicular to the fibers on side A, parallel to the fibers on side $\mathrm{B}$. The original cutting lines have been preserved on all four sides. The top left corner is broken off. A large hole on the right side of the papyrus has caused the loss of one to three letters at the beginning of lines 3-5. Several smaller holes have not damaged the text significantly. At the top, a fiber has broken off along the entire width of the papyrus without damaging the text. The writing shows features typical of the script used in papyri from the first two centuries of the hijra: ${ }^{5}$ the $d \bar{a} l / d h \bar{a} l$ has a rightward bend at the top (e.g., 1. $2^{\prime} a b d ; 1.4$ ahmadu; alladh $\bar{\imath}$; the $d \bar{a} d$ is horizontally extended with straight

of animals that takes place during the b̧ajj at Minā. This text is being prepared by Ayman Shahin for publication.

${ }^{4}$ I would like to thank Fred Donner (University of Chicago) for his permission to publish this papyrus, and Raymond Tindel and Helen McDonald of the Oriental Institute Museum for their help in obtaining photographs and information about it.

${ }^{5}$ Cf. Khan in P.Khalili I, pp. 27-39. parallel horizontal strokes (1. 8 hadda); the horizontal stroke of the initial 'ayn and ghayn is extended to the right (1. 2 'abd; 1.12 ghayr; 1.13 'alayka); the initial and medial $k \bar{a} f$ is horizontally extended with the upper stroke parallel to the lower horizontal (1. 6 dhakartu; 1 . 12 takallafanna); the tail of the final $y \bar{a}$ ' has a marked extension to the right in a horizontal line (1. 2 ila $; 1$.

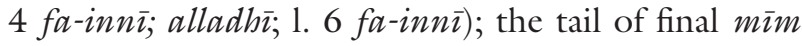
is very short (1. 1 bi-sm; 1.3 muslim; salām). The final $n \bar{u} n$ in $i b n$ is written as a vertical line extending far below the line, but elsewhere shows a horizontal bend at the bottom (e.g. 1.7 al-mu'minin; 11. 9, 10, 11 in). There are ink traces at the end of line 10 belonging to an erased text. There are no diacritical dots.

\section{Text}

Side A:

3
3
3
5




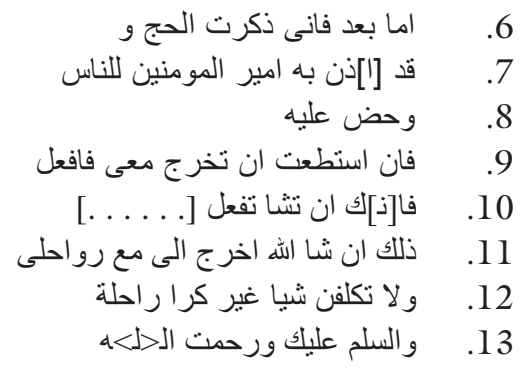

Side B:

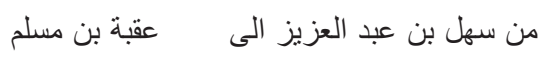

\section{Translation}

Side A:

1. In the name of God the Compassionate, the Merciful,

2. from Sahl son of 'Abd al-Azīz to

3. 'U]qba son of Muslim. Peace be upon you

4. and I thank for your sake God besides Whom

5. there is no] god but He.

6. Now then, I have mentioned the pilgrimage (bajj).

7. The commander of the believers has proclaimed it to the people

8. and he has exhorted (them) to it.

9. So if you are able to go out with me, then do so,

10. for, [i]f you want to do [..... ]

11. this, God willing. Go out to me with my riding camels

12. and do not oblige yourself to anything besides the rental costs of a camel.

13. Peace be upon you and the mercy of $\mathrm{G}<\mathrm{O}>\mathrm{d}$.

Side B:

From Sahl, son of 'Abd al-Azīz, to 'Uqba son of Muslim

\section{Commentary}

1. 2. The first two letters of "Sahl" are damaged, leaving only the top of the three teeth of the sin and the top of the $h \bar{a}$ ' visible. The name has been reconstructed on the basis of its appearance in the address on side $B$. The practice of starting a letter with the names of the sender and addressee after the basmala was current in the first-second/seventheighth centuries (cf. Khan in P.Khalili I, p. 25).

1. 3. The 'ayn in 'Uqba is lost in the lacuna at the beginning of this line, but the name is securely read on the basis of its appearance on side B. For the identification of these two men, see below ("Dramatis Personae").

11. 3-5. Salām 'alayka fa-inñ̄ aḥmadu ilayka allāh alladh $\bar{\imath} \bar{a}$ ilāh illā huwa. This opening greeting is used in letters dating from the first-second/seventh-eighth centuries. ${ }^{6}$ The beginning of line 5 is reconstructed on the basis of parallels. Salām is written with scriptio defectiva of long a (cf. Hopkins \$9.c) as it commonly appears in the papyri. This word is written this way also in line 13. Although the papyrus is broken off at the beginning of line 4 , no text is lost. The open space at the end of this line separates two sections of the letter. ${ }^{7}$ See also the space left open at the end of line 8.

1. 7. Qad [a]dhdhana bibi amīr al-mu'minin li-'l-nās. This phrase echoes Q 22:27, wa-adbdhin fì 'l-nāsi bi-'l-hajji. See also below ("The Caliph's Hajj"). Traces of the alif in adhdhana can be detected before the $d h \bar{a} l$. The last letter is too large and has too much curvature to be read as $r \bar{a}$ and should instead be read as a final nūn (cf. 1. 1, rahmānn; 1. 7, mu'minin; 11. 9, 10 and 11 , in; 1. 12, takallafanna). Qad functions here as a "boundary of a discourse span." Amīr al-mu'minin is the title generally used in contemporary Greek and Arabic papyri for the caliph: see, for example, its use in the protocols dating to the second/eighth century, in Greek amir almoumnin, ${ }^{9}$ and in other texts, such as those demanding provisions in name of/for the caliph. ${ }^{10}$ In Greek, the new term protosymboulos was introduced for the caliph (CPR VIII 82, dating

${ }^{6}$ Cf. Khan in P.Khalili I 14.2, commentary and pp. 62-63; E. M. Grob, Documentary Arabic Private and Business Letters on Papyrus. Form and Function, Content and Context. Archiv für Papvrusforschung Beihefte 29 (Berlin, 2010), 39-41.

${ }^{7}$ Ibid., 189.

${ }^{8}$ G. Khan, Studies in Semitic Syntax. London Oriental Series 38 (Oxford 1988), 42, cited by Grob, Documentary Arabic Private and Business Letters, 142.

${ }^{9}$ Chrest.Khoury I 1-6; P.Cair.Arab. I 1-18.

${ }^{10}$ E.g., Arabic: P. M. Sijpesteijn, "Army Economics: An Early Papyrus Letter Related to 'Ațā' Payments," in R. Margariti, A. Sabra, and P. M. Sijpesteijn, ed., Histories of the Middle East: Studies in Middle Eastern Society, Economy and Law in Honor of A. L. Udovitch (Leiden, 2011), 245-68; Greek amir almoumnin: CPR XXII 45.2,8, eighth century, provenance unknown; P.Lond. IV 1338.12; 1342.2 , both dated to $709 ; 1349.20$, dated to 710 , provenance of all is Ishqūh. Greek amiras tōn pistōn: P. Apoll. 37.10, dated to 708-709, provenance Edfū. 
from 699/700, provenance Fayyūm). ${ }^{11}$ Khalīfa was first used on coins issued under 'Abd al-Malik (r. 65-86/685-705), but is attested on papyrus for the first time only in the second/eighth century. ${ }^{12}$ In Greek sources, khaliffa appears much later. ${ }^{13}$

1. 8. Wa-badda 'alaybi. This verb is used in literary sources for the call to believers to fulfill their religious duties; cf. yahuddu 'alā 'l-zakāt.14

1. 9. In istata'ta. For the significance of this verb, see below ("The Caliph's Hajp”).

11. 10-11. Fa-innaka in tasha' taf'al [...... dhālika in sha'a allāh ukbruj ilayya ma'a rawāhilī. The nūn of innaka is lost in the lacuna but the restoration is certain. The postvocalic hamza in sha'a is not written (cf. Hopkins $\$ 20 . c$ ). Some text is lost on the blank space at the end of line 10, containing the result clause (with $f \bar{a}$ plus a command) and ending with in sha'a allāh, God willing. Open spaces in letters are used to set apart different sections of a text, ${ }^{15}$ a technique effectively used in this letter in lines 5 and 8 , but which does not serve a function

${ }^{11}$ This unique, but correct reading refers to the caliph 'Abd al-Malik (r. 65-86/685-705) and appears also in literary sources such as Theophanes (d. ca. 818) for Mu'āwiya (AM 6171 in Chronographia, ed. C. de Boor [Hildesheim, 1963-1965], 356, tr. C. Mango; and R. Scott, The Chronicle of Theophanes the Confessor [Oxford, 1997], 497), who is otherwise described as archēgos (AM 6169). Cf. A. Grohmann, "Der Beamtenstab der arabischen Finanzverwaltung in Ägypten in früharabischer Zeit," in Festschrift Oertel (Bonn, 1964), 120 n. 4; A. Kazhdan, "Where, When and by Whom was the Greek Barlaam and Iosaph Not Written," in W. Will, ed., Zu Alexander d. Gr. Festschrift G. Wirth zum 60. Geburtstag (Amsterdam, 1988), 1203-1204 and 1208-1209; F. Morelli, "Consiglieri e comandanti: i titoli del goverantore arabo d'Egitto symboulos e amīr," Zeitschrift für Papyrologie und Epigraphik 173 (2010): 158-66.

${ }^{12}$ Referring to the Caliph Hishām (r. 105-125/724-743). It is written in the margin of an unpublished Arabic literary papyrus kept at the Institut Français d'Archéologie Oriental. For the coins, see P. Crone and M. Hinds, God's Caliph (Cambridge, 1986), 7, 24 n. 1.

${ }^{13}$ Discussed together with the other renditions of early Muslim rulers' titles in the documentary and literary evidence in P. M. Sijpesteijn, Shaping a Muslim State: The World of a Mid-EiabthCenturv Eavptian Official (Oxford, 2013), section 3.2.1.

${ }^{14}$ Ibn 'Abd al-Hakam (d. 257/871), Futūh Mișr, ed. C. Torrey, The History of the Conquests of Egypt, North Africa and Spain (New Haven, 1922), 140. See also haddahum 'alā 'l-șadaqa in Ibn Kathīr (d. 774/1372), Tafsīr al-Qur'ān al-'azīm, ed. M. alSayyid Muhammad, et al. (Cairo 1421/2000), 3:335; haddahum 'alō 'l-ṣalāt in Abū Dāwud (d. 275/889), Sunān, Kitāb al-Salāt. $B \bar{a} b$ fi man yanșarifu qabla al-imām., ed. K. Y. al-Hūt (Beirut, 1409/1988), 1:225 no. 624.

${ }^{15}$ Grob, Documentary Arabic Private and Business Letters, 189. in this line. The ink traces visible at the end of line 10 also probably do not belong to the previous text that had covered the whole papyrus (a palimpsest), as there are no traces visible elsewhere on the papyrus and one would have expected words to have been written over the erased part in this line. Another possibility is that the words originally written here were not lost accidentally, but intentionally erased after the letter was completed, perhaps to correct some mistake or the erroneous repetition of words. The erasing was probably not done during the writing, as one would have expected other words to have been written over it. Because of the lack of ink traces on the rest of the papyrus, a single erasure in this part of the papyrus is more likely.

Ilayya is written with a hardly distinguishable final $y \bar{a}$, quite unlike $i l \bar{a}$, which is written with a backbending final $y \bar{a}$ ' in line 2 . See also the combination lām-final $y \bar{a}$ ' in rawāḅili (1. 11).

Rawāhilì. Camels were used in Egypt for transportation of goods and humans. ${ }^{16}$ Rābila is used in narrative texts mostly for riding-camels rather than transport- or breeding-camels, especially in the context of the hajj. ${ }^{17} \mathrm{Jamal}$ (pl. ajmāl) is attested in papyri in contexts of farm animals. ${ }^{18}$ In a third/ninth-century letter, the addressee is asked to come to the sender with some camels (ajmāl) to transport wheat (P.Heid.Arab. II 18, provenance not mentioned).

1. 12. Takallafanna is the energetic form of the imperative of form VI. ${ }^{19}$ The modus energicus is used quite frequently in early letters on papyrus. See especially the Qurra b. Sharik correspondence, ${ }^{20}$ but

${ }^{16}$ D. Müller-Wodarg, "Die Landwirtschaft Ägyptens in der frühen 'Abbāsidenzeit 750-969 n. Chr. (132-358 d. H.)," Der Islam 32 (1957): 141-45; Ch. Pellat "Ibil," EI2, 3:665-68.

${ }^{17}$ al-Maqrīzī (d. 845/1442), al-Mawā'iz wa-'l-i'tibār fì dhikr al-khitat wa-'l-āthār, ed. A. F. Sayyid (London, 2002-2003), 2:132.

${ }^{18}$ P.Cair.Arab. VI 365.1, third-fourth/ninth-tenth century, provenance al-Ashmūnayn; J. David-Weill, "Papyrus arabe du Louvre II," Journal of the Economic and Social History of the Orient 14 (1971): 1-24, no. 11.13, third/ninth century, provenance unknown.

${ }^{19}$ Cf. W. Wright, A Grammar of the Arabic Language (Cambridge, 1896-1898), $\$ 21$.

${ }^{20}$ C. H. Becker, "Neue arabische Papyri des Aphroditofundes," Der Islam 2 (1911): 12.10; P.Qurra 1.12; P.Cair.Arab. III 150.13, all dated 90/709; P.Heid.Arab. I 1.14; Becker, "Neue," 8.14; P.Qurra 2.13, all dated 91/710; provenance of all is Ishqūh. 
also in P.Berl.Arab. II 24.10, first-second/seventheighth century, provenance not mentioned. ${ }^{21}$

The hamza is not written in shay'an (cf. Hopkins $\$ 19)$. Postvocalic hamza is not written in kir $\bar{a}$, (cf. Hopkins $\$ 20 . c$ ). Kir $\bar{a}$ ' is written with a very small initial $k \bar{a} f$. Reading the word as jir $\bar{a}$, "rental fees," which would fit syntactically and interpretatively, is impossible because intial $j \bar{\imath} m / h \bar{a} \bar{a}^{\prime} / k h \bar{a}$ ' are written very differently in this text (cf. 1. 1, rahmān; 1. 11, ukbruj; 1. 12, rāhila, etc.). Kirāa' appears in the papyri with the sense of the cost for the rent of a transport animal. ${ }^{22}$ Cf. balagha kir $\bar{a} \bar{\imath}$ min rashīd ilā 'l-iskandariyya dīnār illā nisf qūr $\bar{a} \cdot t^{23}$ al-kira..$^{24} \mathrm{Al}$-mukārī is a well-attested laqab, meaning transport-animal renter or driver (P.Heid.Arab. II 24.13 , second/eighth century, provenance not mentioned $\left.^{25}\right)$.

1. 14. Rahmat allāh. The tā' marbutta is written in the status constructus with tē' maftūha (cf. Hopkins $\$ 47 . a)$. The scribe erroneously left out one $l \bar{a} m$ in allāh (cf. Hopkins $\$ 52 . a$ ).

\section{Dramatis Personae}

The palaeography and formulae (11. 2-3; $3-5 ; 13$ ) date this letter to the first or beginning of the second century of the hijra. ${ }^{26}$ On the basis of the people mentioned in it, we can place it even more precisely: Sahl b. 'Abd al-'Azìz can be identified as a son of the governor of Egypt, 'Abd al-'Azīz b. Marwān (in office 6586/684-705), who was heir apparent to his brother, the caliph 'Abd al-Malik b. Marwān. ${ }^{27} \mathrm{~A}$ son of that

\footnotetext{
${ }^{21}$ Hopkins is thus no longer correct in saying that the energetic is "common in Aphrodito papyri only" (\$67 and p. 276).

${ }^{22}$ The term is also used for the renting of property up to the Fatimid period (e.g., P.Khalili I 5.2, third/ninth century, provenance not mentioned) after which forms of the root 'jr were used.

${ }^{23}$ P. M. Sijpesteijn, "Travel and Trade on the River," in P. M. Sijpesteijn and L. Sundelin, ed., Papyrology and the History of Early Islamic Egypt (Leiden, 2004), 115-52, 11. 4-5, dating from 117/735, provenance Fayyūm.

${ }^{24}$ P. Heid.Arab. II 29.8, third/ninth century, in which Diem discusses in the commentary that the word must refer to the renting of the animals used to transport goods (flax or linen in the case of this letter).

${ }^{25}$ For examples in the Geniza material, see W. Diem and H. P. Radenberg, Dictionary. The Arabic Material of S. D. Goitein's A Mediterranean Society (Wiesbaden, 1994), 188.

${ }^{26}$ See above note 5 and the commentary on 11.2 and $3-5$.

27 al-Balādhurī (d. 279/892), Ansāb al-ashrāaf 4.1, ed. I. 'Abbās (Wiesbaden, 1979), 422; al-Ṭabarī (d. 310/923), Ta'rīkh al-ru-
}

name is well-attested in the sources. Sahl's mother is known as Umm 'Abd Allāh, daughter of 'Abd Allāh b. 'Amr b. al-'Āṣ (d. ca. 65/684) and granddaughter of the famous conqueror of Egypt, 'Amr b. al-'Ās (d. 42/663). Umm 'Abd Allāh transferred a $d \bar{a} r$ (or darb) and a hammām in Fustāạt to Sahl and his brother Suhayl, which she had inherited from her father. ${ }^{28}$ Sahl's family resided in Fusțāț, where their frequent buying, selling and other transfers and accumulations of property are prevalent themes in the sources. ${ }^{29}$ Sahl is also said to have transmitted some hadiths, ${ }^{30}$ but he seems otherwise to have kept a low public profile and the sources do not attribute to him any administrative posts. Due to the animosity against the Banū 'Abd al-'Azīz in the capital after 'Abd al-'Azīz's death (see below, "Inter-Umayyad Rivalry"), Sahl probably did not move to Damascus before his half-brother, 'Umar, who was the son of 'Abd al-'Azīz and Umm 'Āṣim Laylā bint 'Āṣim, ${ }^{31}$ became caliph in Șafar 99/September 717.32 The caliph 'Umar II (r. 99-101/717-720) buried Sahl when he died in Damascus in 99/717.33

sul wa-'l-mulūk, ed. M. J. de Goeje et al. (Leiden, 1964-1965), 2:610; al-Mas'ū dī (d. 344/956), Murūj al-dhabab wa-ma'ādin aljawhar, ed. C. Pellat (Beirut, 1970), 3:288-89; Ibn Taghrī Birdī (d. 874/1470), al-Nujūm al-zābira fì mulūk Miṣr wa-'l-Qābira (Cairo, 1929-1972), 1:172.

${ }^{28}$ The $d \bar{a} r$ Sabl is said to have housed the saddlers and it is also called the darb al-sarrājīn (Ibn 'Abd al-Hakam, Futūh, 112). For the bammām Sabl, see ibid., 112 and 121.

${ }^{29}$ Ibn 'Abd al-Hakam, Futūh, 92, 95, 98, 103, 104, 113, 114, 133. A 'Aqabat Sahl was located in Fusțāt (Ibn Duqmāq [d. 809/1407], al-Intișār li-wāsitat 'iqd al-amșār, ed. K. Vollers [Cairo, 1310/1893], 4:51).

${ }^{30}$ al-Ṣafadī (d.764/1383), al-Wāfì bi-'l-wafayāt, ed. W. al-Kāḍī (Wiesbaden, 1982), 16:6-7 s.v. Sahl b. 'Abd al-'Azīz.

${ }^{31}$ For Umm 'Āṣim Laylā bint 'Āṣim bint 'Umar b. al-Khațtāa, see al-Ṣafadī, al-Wāfi bi-'l-wafayāt, ed. R. Baalbaki (Wiesbaden, 1983), 22:506-10. From this marriage, two sons were born, 'Umar and Abū Bakr 'Āṣim, the latter of whom fathered yet another Sahl with his wife, Umm Sahl bint Maslama (al-Balādhurī, Ansāb alashrāf 5, ed. I. 'Abbās [Beirut, 1996], 531; Ibn 'Abd al-Hakam, Futūh, 100).

32 'Umar himself had probably already been living in Damascus since 93/711, after being dismissed as governor of Medina (alTabarī, Ta'rīkh, 2:1354). He undertook the pilgrimage with the caliph Sulaymān (r. 96-99/714-717) in 97/716 (P. M. Cobb, "Umar [II] b. 'Abd al-'Azizz,' EI2, 10:821).

${ }^{33}$ No specific month for Sahl's death is given (Ibn Taghrī Birdī, Nujūm, 1:241; Ibn Manz̄ūr [d. 711/1311], Mukhtașar ta'rīkh Dimashq, ed. R. al-Naḥhās [Damascus, 1986], 10:223, no. 128; al-Ṣafadī, al-Wāfì, 16:6-7). 'Umar b. 'Abd al-'Azīz was informed about his other brother Suhayl's death by his officials, suggesting that Suhayl was not resident in Damascus at the time (Ibn Qutayba [d. 276/889], 'Uyūn al-Akbbār [Cairo, 1348/1930], 3:54). 
Two of Sahl's sons, Muhammad and 'Amr, ${ }^{34}$ and several of his mawāli, clients or freedmen, are mentioned in the sources. ${ }^{35}$

The recipient of our letter is probably the 'Uqba b. Muslim al-Tujibī (d. ca. 120/737), ${ }^{36}$ who was appointed deputy governor of Fustạt ț when the governor of Egypt, Hanzala b. Șafwān (in office 102-105/720723 ), temporarily moved to Alexandria in $103 / 721 .{ }^{37}$ In $105 / 723$, Hanzala was replaced by Muhammad b. 'Abd al-Malik (in office 105/723) as governor of Egypt, but it is not stated whether 'Uqba remained in charge of Fustāt until this time. ${ }^{38}$ 'Uqba's nisba indicates that he belonged to the Arab tribe of Tujīb, which made up one of the largest units of the Arab army with which 'Amr b. al-'Āṣ conquered Egypt. ${ }^{39}$ 'Uqba was also appointed storyteller (qūsss or 'alā 'l-qașaș) and prayer leader (imām) at 'Amr b. al-'Āṣ's mosque (al-masjid al-jamī'al-'atīq) until his removal from that double-post in $118 / 735$. The congregation-'Uqba is quoted to have said-was very satisfied with him, for when leading them in prayer, he would shorten the prayer if they thought it too long,

\footnotetext{
34 'Amr was a follower of the 'Alid rebel 'Abd Allāh b. Mu'āwiya (d. 129/746-747) fleeing from Marw to Egypt at the latter's defeat (Ibn Taghrī Birdī, Nujūm, 1:351; al-Ṭabarī, Ta’'rīkh, 2:1979; Ibn al-Athīr [d. 630/1233], al-Kāmil fì 'l-ta'rīkh, ed. C. J. Thornberg [Leiden, 1871], 5:372).

${ }^{35}$ For the mawāli of Sahl, see al-Dhahabī (d. 748/1348), Ta'rīkh al-Islām wa-tabaqāt al-mashāhir wa-'l-a`làm, ed. 'U. 'A. S. Tadmurī (Beirut, 1410/1990), 5:63; al-Mizzī (d. 742/1341), Tahdhīb al-kamāl fì asmā' al-rijāl, ed. B. 'A. Ma'rūf (Beirut, 19851992), 34:60, no. 7497, and for the mawāt see al-Mizzī, Tahdhīb, 6:33, no. 1193

${ }^{36}$ Ibn Hajar (d. 852/1449) and al-Mizzī wrote that 'Uqba died around 120/737 (Tahdhīb al-tahdhīb [Hyderabad, 1326/1908], 7:249-250, no. 450; Tahdhīb al-kamāl, 20:222-223, no. 3987). $\mathrm{Al}$-Maqrīzī lists the names of those in charge of reading and judging in the 'Amr b. al-'Ạs mosque in Fusțāt and mentions that 'Uqba b. Muslim al-Hamdānī was replaced as the reader and judge of this mosque in the year 118/735 (Khitat, 4:31), a decision he is said to have protested, according to Ibn 'Abd al-Hakam (Futūh, 243).

${ }^{37}$ al-Kindī (d. 350/961), Kitā̄b al-Wulāt wa-kitāb al-qudāt, ed. R. Guest, The Governors and Judges of Egypt (Leiden, 1912), 71; Ibn Taghrī Birdī, Nujūm, 1:250; al-Maqrīzī, Khitaț, 2:50.

${ }^{38}$ al-Kindī, Wulāt, 72 .

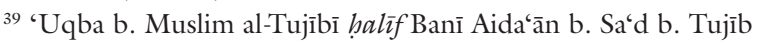
(al-Kindī, Wulāt, 71). Guest (Governors and Judges) did not identify this subtribe of the south-Arabian tribe of Kinda (al-Kindī, Wulāt, 71 , n. 2), for which see W. Caskel, Jambarat al-Nasab. Das geneaologische Werk des Hišām b. Muhammad al-Kalbū (Leiden 1966), 2:52-53. For the tribe of Tujīb participating in the conquest, see Guest's introduction to al-Kindī, Wulāt, 5 .
}

and lengthen it if they thought it too short. ${ }^{40} \mathrm{He}$ was also a well-known transmitter of hadith from, amongst others, 'Amr b. al-'Āṣ's son, 'Abd Allāh, who was also Sahl's grandfather. ${ }^{41}$

The topic of the letter and the reference to the amìr al-mu'minin place it immediately in the milieu of Egypt's ruling élite. The sources do not discuss any direct relation or encounter between Sahl and 'Uqba, but both men were members of the social and political Arab-Muslim upper class of late seventh-century Egypt. There are several reasons to suggest that the relationship between the sender and recipient of this letter was even closer than that of merely fellow members of Egypt's ruling élite. First, at a time when the total number of Muslims in Egypt was still very limited, the paths of these two men must have crossed regularly. The fact that 'Uqba had received hadiths to transmit from Sahl's grandfather confirms that they had ample occasion to meet. And the language with which the issue of going on pilgrimage is framed (line 6, dhakartu = "I mentioned") indicates that Sahl and "Uqba were returning to a topic they had discussed before.

But if 'Uqba and Sahl were peers, operating in the same milieu, why did 'Uqba seem to have an access to Sahl's camels that Sahl himself did not? Sahl asked 'Uqba to join him on the pilgrimage and then ordered him to come to him, bringing Sahl's camels along. 'Uqba was obviously not in the same place as Sahl when he received the letter. One possibility is that 'Uqba had gone to the countryside to supervise the grazing of Sahl's camels, since we know that camel herds were typically taken into the countryside during the spring to graze in preparation for the campaigning season. ${ }^{42}$ It is not unreasonable to assume that the same was done for the pilgrimage season.

On the surface, this is all that our papyrus tells us, and we could stop our interpretation at this point.

${ }^{40}$ Ibn 'Abd al-Hakam, Futūh, 243; al-Dhahabī, Ta'rīkh al-Islām, 7:425, no. 499; Ibn Hajar, Tahdhīb, 7:249-250, no. 450; al-Mizzī, Tahdhīb, 20:222-23, no. 3987.

${ }^{41}$ Ibn 'Abd al-Hakam, Futūh, 293, 299, 300, 310; Ibn Hajar, Tahdhīb, 7:249-50, no. 450; al-Mizzī, Tahdhīb, 28:111-112; al'Ijlī (d. 261/874), Ta'rīkh al-thiqāt, ed. 'A. M. Qal'ajī (Beirut, 1984), 338, no. 1153; al-Dhahabī, Ta'rikh al-Islām, 7:425, no. 499; al-Bukhārī, al-Ta'rīkh al-kabīr (Hyderabad, 1390/1970), 3/2:437, no. 2909.

${ }^{42}$ P. M. Sijpesteijn, "New Rule over Old Structures: Egypt after the Muslim Conquest," in H. Crawford, ed., Regime Change in the Ancient Near East and Egrpt: From Sargon of Agade to Saddam Hussein (London, 2007), 187. 
Placing this letter in a late first/seventh-early second/eighth-century historical context, however, allows for some speculation about several other layers of meaning.

\section{The Caliph's Hajj}

Why did the caliph need to announce that it was time to undertake the pilgrimage? The bajj, after all, takes place every year on the same dates of the lunar calendar, namely during a five-day period from the eighth to the twelfth of the last lunar month of the Muslim calendar, Dhu ' 'l-hijja. Yet it was not so much the time of the hajj that the caliph announced in this letter, but the moment at which his caravan or the one he sponsored would depart for Mecca. ${ }^{43}$ As will become clear, it was of the utmost importance to our letter's caliph that Sahl and would-be pilgrims like him be made well aware of this information.

How did Sahl know the caliph had announced that the time for the bajj had arrived, and how literally should we interpret Sahl's reference to the caliph's announcement? The announcement that it was time to go on bajj was probably made publicly in the different provinces of the Islamic Empire, possibly in name of the caliph, for example in the main mosque during the Friday prayer. ${ }^{44}$ Sahl's close connection to the ruling family, on the other hand, does not exclude the possibility that he received a letter directly from Damascus. Sahl was himself probably in Egypt, where this papyrus was found, when he heard about the caliph's announcement which he then transmitted in his letter to 'Uqba, as it is unlikely that he would have ordered his camels to be brought all the way from Egypt to Damascus. ${ }^{45}$

\footnotetext{
${ }^{43}$ In a much later period, the eleventh-century traveller Nāṣir-i Khusraw described a similar situation, when he heard the Fāțimid sultan's representatives announce in Cairene mosques in the month of Rajab of the year 440/1048 that the bajj caravan would leave in five months' time (Nāṣir-i Khusraw, Naser-e Khosraw's Book of travels [Safarname], tr. W. M. Thackston Jr. [New York, 1986], 58-59).

${ }^{44}$ I am grateful to Wadād al-Kāẹī for this suggestion. See also the examples of publicly-announced decrees under the Marwānids, especially concerning the succession: H. Munt, "The Official Announcement of an Umayyad Caliph's Successful Pilgrimage to Mecca," in V. Porter and L. Saif, ed., The Hajj: Collected Essays (London, 2013): 15-20, 17 and nn. 33, 34; A. Marsham, Rituals of Islamic Monarchy: Accession and Succession in the First Muslim Empire (Edinburgh, 2009), 155-59.

${ }^{45}$ Theoretically, 'Uqba could have received this letter outside Egypt and brought it with him to Egypt, where it was later found.
}

The hajj is every individual Muslim's responsibility as expressed in God's command: "Pilgrimage to the House (bayt) is a duty for all who are able to make the journey (Q 3:97)." "46 Legal and religious texts written down from the end of the second/eighth century onwards set out in detail the ceremonies pilgrims were (and still are) to undertake in Mecca and its immediate surroundings, basing their prescriptions on the way the prophet Muhammad himself performed these rituals during his "farewell pilgrimage" in the year $10 / 632$, but also in details provided in the Qur'ān (for example Q 2:196-203 and 22:27-36). ${ }^{47}$

Sahl refers to this duty to perform the hajj in his letter when he tells "Uqba, "So if you are able to go out with me then do so" (1. 9), ${ }^{48}$ using the same verb (istat $\left.\bar{a}^{\prime} a\right)$ as the Qur'ānic command mentioned above. ${ }^{49}$ But there might be yet another aspect to this letter to which we will turn next.

Muhammad's appropriation of the hajj after his conquest of Mecca assured the ruler of the umma access to and control of the pilgrimage. The prophet Muhammad's being in charge was symbolised by his recently-appointed governor of Mecca, 'Attāb b. Asīd (d. 13/634) or Abū Bakr al-Ṣiddĩq (d. 13/634), who led the pilgrimage on the first hajj after the city's capture in the year $8 / 630 .{ }^{50}$ Being in control of the two holy cities of Islam in Arabia and the pilgrimage to Mecca conferred vital prestige and religious appeal on subsequent Muslim rulers. The caliph's association with the yearly pilgrimage extended from his own leadership and participation to the patronage and organization of the pilgrims and their journey. ${ }^{51}$ One way

There is, however, no indication in the sources that he spent time outside of Egypt.

${ }^{46}$ Wa-li-lāhi 'alā 'l-nāsi hijju'l-bayti man istațā'a ilaybi sabilan; see also Q 2:119, 196, 197-199; 3:91, 97; 5:2, 95, 97; 9:17-18; 22:27-30.

${ }^{47}$ But the sources disagree about the details performed by Muhammad during his hijjat al-wad̄̄'(Munt, "Official Announcement," 18). For an historical analysis of these rituals, see S. Hurgronje, Het Mekkaanse Feest (Leiden, 1880), translated by L. I. Conrad and P. M. Sijpesteijn, The Meccan Feast (Princeton, NJ, forthcoming).

${ }^{48} \mathrm{Fa}$-in istata'ta an takhruja ma'i $f a-' f$ 'al.

${ }^{49}$ See above n. 46.

${ }^{50}$ For 'Attāb b. Asīd, see Ibn Hishām (d. 218/833), Sīrat Ras̄̄ l Allāh, tr. A. Guillaume (Oxford, 1978), 597; al-Azraqī (d. ca. 250/864), Kitāb Akbbār Makka, ed. F. Wüstenfeld, Chroniken der Stadt Mekka (Leipzig, 1858), 127-28. For Abū Bakr (r. 1113/632-634), see al-Ṭabarī, Ta'rīkh, 1:1670.

${ }^{51}$ For the significance of the caliph's personal participation in the bajj, see Munt, "Official Announcement," and, in general, for the 
in which this patronage was expressed was through the caliph's appointment of the $i m \bar{a} m$ leading the pilgrims in and around Mecca in prayer and giving the sermon on mount 'Arafāt. This office was generally reserved for the governors of Mecca or Medina, whose names have been recorded from the time of Muhammad onwards in the historical sources. ${ }^{52}$ Another important caliphal appointment was the amir al-bajj who, under the Umayyads, was most often chosen from among the caliph's family or was a closely related governor or other official. ${ }^{53}$ Accounts of Abbasid times describe the caravans setting off from the different provinces as having been led by separate ami $r$ s, but for the early Umayyad period, such amīrs of local pilgrim caravans

political dimension to the hajj in the early period, M. E. McMillan, The Meaning of Mecca. The Politics of Pilgrimage in Early Islam (London, 2011). See also the buildings erected along the pilgrimage routes dating from the Abbasid period to facilitate the pilgrims' journeys (S. al-Rashid, "Ancient Water Tanks on the Hajj Route from Iraq to Mecca and Their Parallels in Other Arab Countries," Atlal 3 [1979]: 55-62; M. Gilmore et al., "Darub al-Hajj. Architectural Documentation Program Report on the Architectural Survey of the Northern Pilgrim Routes, 1403/1983," Atlal 8 [1984]: 143-64; K. al-Dayel and S. al-Helwa, "Darb Zubayda Survey Project. Preliminary Report on the Second Phase of the Darb Zubayda Reconnaissance 1397/1977," Atlal 2 [1978]: 51-64; A. al-Mughannam et al., "Catalogue of Stations on the Egyptian (Coastal) and Syrian (Inland) Pilgrim Routes," Atlal7 [1983]: 42-75; S. Tamari, "Darb al-Hajj in Sinai and Historical-Archaeological Study," Atti dell Accademia Nazionale dei Lincei 25 [1981]: 427-525; S. A. al-Rashid and M. J. L. Young, "Darb Zubayda,” EI2 Suppl., 198-99).

${ }^{52}$ See the names generally mentioned in al-Tabarī's history at the end of each year. E.g., Abū Bakr b. Muhammad b. 'Amr led the people in pilgrimage ( hajja bi-'l-nās) while governor of Medina in the years 99/718 and 100/719. 'Abd al-Rahmān b. al-Dahhāk led the pilgrimage in 101/720 as governor of Medina and in 102/721 as governor of Mecca (al-Tabarī, Ta'rīkh, 2:1346, 1358-59, 1394, 1436).

${ }^{53}$ Without being described as "led" by umarā' al-hajj, our sources hint that already under the Umayyads, caravans headed by prominent Umayyads were being organised in and despatched from Syria. Hishām was the last caliph to lead the pilgrimage himself in the year 106/725 (al-Ṭabarī, Tar'îkh, 2: 1482-83. Cf. 'Abd al-Hamīd al-Kātib's letter written after the caliph returned from hajj. The Arabic edition appears in: I. 'Abbās, ed., 'Abd al-Hamīd

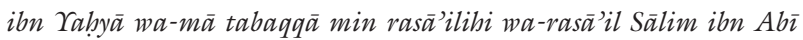
'l-'Alā' ('Ammān, 1988), 205-206, no. 11; translation and discussion by Munt, "Official Announcement." For the years 112/731 and $113 / 732$, al-Ṭabarī writes that Ibrāhīm b. Hishām led the people in the pilgrimage, but also that "it is said that the one leading the people in pilgrimage this year was Sulaymān b. Hishām," probably meaning he led the pilgrimage caravan from Syria where he is otherwise said to have resided (al-Tabarī, Tar'̄̄kh, 2:1559). Similarly, in the year 116/735 al-Walīd b. Yazìd, the heir apparent, led the pilgrimage, probably travelling with a caravan from Syria (al-Ṭabarī, Tar'īkh, 2:1572). are not known. We do not know, therefore, whether 'Uqba and Sahl were part of an Egyptian caravan, joining the Syrian one in Ayla (modern-day 'Aqaba) as later accounts about the Egyptian pilgrimage caravans relate, ${ }^{54}$ or whether they travelled together, joining the caliph's caravan somewhere in Syria or elsewhere. ${ }^{55}$

How significant this was for the legitimacy of the caliph is best expressed by the third/ninth-century historian al-Ya'qūbī: "He who controls the two sanctuaries Mecca and Medina and leads the pilgrimage thus merits the caliphate." ${ }^{\prime 56}$ Al-Ya'qūbī wrote these words about a period when control of the caliphate was contested and power struggles were fought over and on the pilgrimage itself. We will now examine how this particular historical context also relates to our letter, providing it with yet another possible layer of significance.

'Abd Allāh b. al-Zubayr (d. 73/692), an eminent early Muslim and member of Muhammad's tribe of Quraysh, successfully used his distinguished position to challenge the Umayyad caliphate in Damascus politically and religiously for more than ten years. Ibn al-Zubayr refused to swear allegiance to the second Umayyad caliph, Yazīd b. Mu'āwiya (r. 60-64/680683), whose father had appointed him successor to the caliphate during his own lifetime. Yazīd ruled three and a half years, ${ }^{57}$ but after the death of his son, Mu'āwiya II, who ruled for a few months only, no suitable successor to the caliphate was found in the Sufyanid family, leaving a power vacuum. Ibn alZubayr, whose popularity had grown substantially, received the bay' $a$ as caliph in Mecca where he resided and from thence ruled a large part of the Islamic empire..$^{58}$

\footnotetext{
${ }^{54}$ Ibn Hawqal (d. after 362/973), Kitāb șūrat al-ard, ed. J. H. Kramers (Leiden, 1967), 39.

55 'Amr b. al-'Āṣ is supposed to have made the pilgrimage traveling via the Red Sea (Ibn 'Abd al-Hakam, Futūh, 166), but the pilgrimage routes from Egypt via the Red Sea did not become popular until the Crusader period (F. E. Peters, The Hajj. The Muslim Pilgrimage to Mecca and the Holy Places [Princeton, 1994], 90-94; J.-C. Garcin, Qūss. Un centre musulman de la haute-Égypte medieval [Cairo, 2005]).

${ }^{56}$ al-Ya'qūbī (d. 284/897), Ta’rīkh, ed. M. T. Houtsma (Leiden, 1883), 2:321.

${ }^{57}$ The sources disagree about the length of his caliphate, some claiming it lasted for three years and eight months.

${ }^{58}$ Lam tabqa nābiya illā mālat ilā 'bn al-zubayr khalā'l-urdunn (al-Ya'qūbī, Ta'rīkh, 2:304). Ibn al-Zubayr was a fully acknowledged caliph next to or opposed by Marwān and 'Abd al-Malik, as is clear from historical sources such as al-Mas'ūdī, who gives two regnal dates for 'Abd al-Malik, counting from the oath of allegiance sworn to him (twenty-one years) and from the moment he defeated Ibn
} 
Ibn al-Zubayr is referred to as amīr al-mu'minin in mainstream chronicles, and every year he was in power in Mecca he led the pilgrimage there. ${ }^{59}$ However, after having received the oath of allegiance on 3 Dhū 'l-Qa'da 64 (June 22, 684) at al-Jābiya, ${ }^{60}$ Marwān and especially his son, 'Abd al-Malik, started to wrest the lost provinces from the Zubayrids. In 65/684, Egypt became Marwān's first conquest, less than a year after the appointment of 'Abd al-Rahmān b. 'Utba as governor of the province by Ibn al-Zubayr. ${ }^{61}$ Only in 73/692, however, after several attempts to oust Ibn al-Zubayr from Mecca, did the Umayyad general al-Hajjāj (d. 95/714) succeed in defeating him, and Ibn al-Zubayr died in battle. With the most significant single rival to the Umayyad caliphate now destroyed and Umayyad control over the holy cities confirmed, symbolized by al-Hajjāj's leading of the pilgrimage in $73 / 692$ and 74/693 and his rebuilding of the Ka'ba in Mecca, ${ }^{62}$ unity in the Islamic empire was restored.

The struggle for power and political and religious authority in the Islamic empire during this second civil war was not only fought geographically around Mecca, but around the pilgrimage itself; its patronage and the leadership of its different rituals became sites of bitter contention. In $62 / 681$, for example, the visit to mount 'Arafāt and the khuṭba (sermon) given there were completed separately by three rival groups of Muslims, one being led by Walìd b. 'Utba, the Umayyad governor of Medina, one by Ibn al-Zubayr, and one by the Khārijite leader Najda al-Harūrī (d. 71/691). ${ }^{63}$ The following years saw competing groups of pilgrims undertake the pilgrimage independently, co-existing uncomfortably during their stay in the holy city, with intermittent clashes and casu-

al-Zubayr and reunited the empire (thirteen years) (Murīj, 3:291). Cf. C. F. Robinson, 'Abd al-Malik (Oxford, 2005), chapter 2. See also al-Maqrīzī (d. 845/1442), who added Ibn al-Zubayr to his list of "caliphs and kings" who performed the pilgrimage, stating that he received the oath of allegiance in the year 64 or 65 , gathering support from the people in the Hijāz, the Yemen, Iraq, and Khurasān (al-Dhahab al-masbük fì dhikr man hajja min al-khulafä' wa-'l-muluk, ed. J. D. al-Shayyāl. [Cairo, 1955], 25).

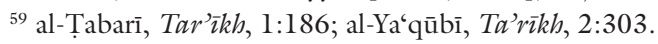

${ }^{60}$ al-Tabarī, Ta'rīkh, 2:474. Other dates are given as well in the sources all around 64-65/683-684.

${ }^{61}$ al-Kindī, Wulāt, 41-48.

${ }^{62}$ al-Ṭabarī, Ta'rīkh, 2:854-855.

${ }^{63}$ G. R. Hawting, "The Hajj in the Second Civil War," in I. R. Netton, ed., Golden Roads: Migration, Pilgrimage and Travel in Mediaeval and Modern Islam (Wiltshire, 1993), 37; al-Ṭabarī, Ta'rikh, 2:222. alties. ${ }^{64}$ In $68 / 687$ there were even four banners at 'Arafāt, one of the pilgrimage stations outside Mecca, representing the Umayyads; the followers of Ibn alZubayr; the Khārijites led by Najda al-Harūrī; and the Iraqi Shī'ites led by Muhammad b. al-Hanafiyya (d. $80 / 700$ ) - all fulfilling their rituals in an atmosphere of high tension. ${ }^{65}$

While Ibn al-Zubayr was in control of Mecca, 'Abd al-Malik preferred pilgrims not to go there, fearing that they would be lured into swearing allegiance to his rival in the holy city. An Arabic chronicle describes how 'Abd al-Malik made pilgrims take the oath of allegiance to him after they returned from the pilgrimage. ${ }^{66}$ The Dome of the Rock in Jerusalem, completed at the caliph's order in $72 / 692$, might have been designed to offer an alternative place of pilgrimage for Muslims. ${ }^{67}$ Whatever 'Abd al-Malik's motivation, it is clear that the erection of this splendid building needs to be understood in the context of a caliphal struggle for power and authority brought to the foreground in the second civil war. 'Abd al-Malik might even have initiated similar alternative pilgrimage ceremonies in other provinces such as Egypt. ${ }^{68}$

${ }^{64}$ In $66 / 686$ the followers of the Alid rebel, al-Mukhtār (d. 67/687) came to Mecca for the hajj, but also to free Muhammad b. al-Hanafiyya (d. 80/700), who was being held prisoner in Mecca and threatened with death by Ibn al-Zubayr (ibid., 2:693). Ibn alZubayr led the pilgrimage from 63/684 to $71 / 691$ (ibid., 2:752, $796,797,818)$. Al-Hajjāj led the pilgrimage outside of Mecca in $72 / 692$ while Ibn al-Zubayr was besieged in the city. In 69/689, a Khārijite was killed during the pilgrimage after calling out: "Judgement belongs to none but God" (ibid., 2:689). When news of the Umayyad caliph Yazīd b. Mu'āwiya's death reached the Syrian army laying siege to Mecca in 64/683, the Syrians asked to be allowed to perform those rituals of the hajj that take place inside Mecca before returning to Syria (ibid., 2:430).

${ }^{65}$ J. Jomier, "Amīr al-hadj," EI2, 1:443, Hawting, "Second Civil War," 37-38; al-Ṭabarī, Ta’rīkh, 2:781-83; Ibn Sa'd (d. 230/845), al-Ṭabaq̄t al-kabìr, ed. K. V. Zetterstéen (Leiden, 1905), 5:75.

${ }^{66}$ al-Ya'qūbī, Ta'rīkh, 2:261.

${ }^{67}$ A. Elad, "Why Did 'Abd al-Malik Build the Dome of the Rock?" in J. Raby and J. Johns, ed., Bayt al-Maqdis. 'Abd al-Malik's Jerusalem (Oxford, 1992), 1:33-58.

${ }^{68}$ 'Abd al-'Azīz is said to have been the first to hold an 'Arafăt ceremony at Fusțāt in the year 71/690 (al-Kindī, Wulāt, 50; alMas'ūdī, Murūj, 3:315-16). In one source, the description of 'Abd al-'Azīz's confirmation as governor by his brother 'Abd al-Malik directly precedes the announcement about the 'Arafāt ceremony, suggesting a causal relationship (Ibn Taghrī Birdī, Nujūm, 1:186). Similarly, the confirmation of 'Abd Allāh b. 'Abd al-Malik as Egypt's governor (in office 86-90/705-709) by the caliph al-Walīd I (r. 8696/705-715) is followed by the information that he changed the dìwān from Coptic to Arabic, presumably following the caliph's order (al-Kindī, Wulāt, 58-59; Ibn Taghrī Birdī, Nujūm, 1:210). 
Besides stimulating 'Abd al-Malik's assertion of his control over and design of certain pilgrimage rituals, Ibn al-Zubayr paradoxically played a role in affirming the religious aspect of 'Abd al-Malik's empire in several other respects as well. Starting immediately after Ibn al-Zubayr's defeat, 'Abd al-Malik launched his famous coin reforms by replacing the images based on Byzantine and Sasanid rulers with religious formulae, following similar changes introduced by Ibn alZubayr. ${ }^{69}$ The rebuilding of the Ka'ba after its capture by al-Hajjāj has already been mentioned, but the bajj ceremony also underwent important alterations after the second fitna, resulting in a more important role for the ceremonies taking place inside the city, such as the circumambulation of the black stone. ${ }^{70}$

How important 'Abd al-Malik's role was in the establishment of these rituals is clear from the following story: when 'Abd al-Malik's son, the caliph Sulaymān (r. 96-99/715-717), encountered contradictory replies to his question how the pilgrimage rituals should be undertaken, he reportedly declared that he would "perform the hajj the way "Abd al-Malik did."71 The importance attributed to the caliph's personal participation in religious rituals seems also to have become more pronounced, with 'Abd al-Malik personally leading the bajj in 75/694, as Ibn al-Zubayr had done in the years $63-71 / 684-691 . .^{72}$

We can therefore explain our letter as an expression for the caliph's authority in organizing the hajj, a role

\footnotetext{
${ }^{69}$ L. Treadwell, "The 'Orans' Drachms of Bishr b. Marwān," in
} J. Johns, ed., Bayt al-Maqdis. Jerusalem and Early Islam (Oxford, 1999), 223-70.

${ }^{70}$ When al-Hajjajj besieged Ibn al-Zubayr in Mecca in 72/692, the rituals that took place inside the city might not have formed an essential part of the bajj, while the sermon at 'Arafât on the other hand did. In this year, the historian al-Tabarī wrote, al-Hajjāj led and completed the pilgrimage, even though he and his men were prevented from going into the city. He describes Ibn al-Zubayr and his companions, on the other hand, as not having finished the bajj in spite of them having replaced the rituals to be performed outside Mecca with rites inside the city (al-Ṭabarī, Ta'rīkh, 2:830-31, 834). But see Harry Munt's reading of the report on the caliph alHishām's pilgrimage in $106 / 725$ as confirming that at that time this situation continued (“Official Announcement," 18-19).

${ }^{71}$ Hawting, "Second Civil War," 36.

72 'Abd al-Malik was not the first Umayyad caliph to do so. The caliph Mu'āwiya (r. 41-60/661-680) had preceded him in 44/665 and 51/671 (al-Tabarī, Ta'rīkh, 2:70; al-Maqrīzī, al-Dhahab almasbūk, 24). Hishām was the last Umayyad caliph to make the pilgrimage. Marwānid caliphs tended to perform the pilgrimage at least once in their lifetime (McMillan, Meaning of Mecca, 133-34; al-Maqrīzī, al-Dhahab al-masbūk, 27-36). that had become more important in the post-Zubayrid period, when Sahl b. 'Abd al-'Azīz and 'Uqba b. Muslim, identified above, would have discussed the pilgrimage by letter. At this time, about ten years after the rivalry and commotion around the pilgrimage and its leadership, the caliph would have attached great importance to his family members joining his pilgrimage caravan, led in its ritual observances in Mecca by a caliphal appointee. That Sahl and 'Uqba belonged to the ruling class of one of the provinces that had sided with Ibn al-Zubayr, and which was deemed so important by Marwān that he reconquered it before any other area in Zubayrid hands, made the caliph's request even more urgent. In this sense the use of the root $a-d b-n$ in our letter is also relevant. The $a d b \bar{a} n$, proclamation, made by Muhammad at the "great pilgrimage" (Q 9:3) signified the prophet's break with the pagan pilgrimage, while at the same time reminding members of the Muslim umma, especially the newly-won Meccans, of their obligations towards the community's leader. ${ }^{73}$ 'Abd al-Malik's rule also signified a watershed moment in the performance of the pilgrimage, as he too needed to remind his subjects of their loyalty towards him. Pilgrimage politics, however, are not the only context in which this text needs to be understood. There is yet another contemporary political dimension that adds a possible third layer to our letter.

\section{Inter-Umayyad Rivalry}

Sahl's father, 'Abd al-'Azīz, had fought at the side of his father Marwān in 65/683 to regain Egypt from the Zubayrids. He had been awarded not only with the governorship of Egypt, but had also been appointed second-in-line to the throne after his brother 'Abd al-Malik. ${ }^{74}$ After their father died, 'Abd al-Malik tried to convince 'Abd al-'Azīz to give up his right to the caliphate in favor of two of his own sons, al-Walid (d.. 96/715) and Sulaymān (d. 99/717). But 'Abd al-'Azīz, in fact, as he wrote his brother, had other ideas, intending to pass the succession on to his own sons. ${ }^{75}$ Thus when 'Abd al-'Azīz died, 'Abd al-Malik, pre-empting his brother's plan, immediately appointed

\footnotetext{
${ }^{73}$ U. Rubin, "The Great Pilgrimage of Muhammad: Some Notes on Sūra IX," Iournal of Semitic Studies 27 (1982): 241-60.

${ }^{74}$ See above, n. 27.

${ }^{75} \mathrm{Abū} \mathrm{Bakr}$ and Aṣbagh are mentioned in this context (alTabarī, Ta’'rīkh, 2:1164-68, 1169-70; Ibn Taghrī Birdī, Nujūm, $1: 173-74)$.
} 
his own sons as successors to the caliphate, cutting out his nephews from access to the throne. ${ }^{76}$ To secure his family's hold on the empire, he appointed yet another of his sons, 'Abd Allāh b. 'Abd al-Malik, governor of Egypt in $86 / 705$, commanding that he "obliterate all traces of his uncle, 'Abd al-'Azīz, because of his (former) place in the succession." 'Abd Allāh b. 'Abd al-Malik obeyed and "replaced ('Abd al-'Azīz's) officials with (his own) officials and ('Abd al-'Azīz's) functionaries with (his own) functionaries." 'U7 'Umar, 'Abd al-'Azīz's son and caliph after two of 'Abd al-Malik's sons (al-Walīd I, r. 86-96/705-715 and Sulaymān, r. 96-99/715-717), seems to have been intended as a symbol of reconciliation between the two families: he was married to 'Abd al-Malik's daughter Fāțima, and was appointed by al-Walīd I as governor of Medina. But the competition continued, and when 'Umar was appointed caliph, opponents pointed out that Marwān had given specific instructions to prevent 'Umar's selection as caliph. 'Umar died after a short reign, and some even speculated that he had been poisoned by dissatisfied members of the Banū 'Abd al-Malik. ${ }^{78} \mathrm{Al}-$ though thus barred temporarily from the throne, the Banū 'Abd al-'Azīz, of which Sahl was a member, remained direct competitors of the Banū 'Abd al-Malik for the caliphal seat. We can thus imagine that our letter was also written to secure a public declaration of loyalty from important Umayyads to the ruling branch of the dynasty by having them undertake the bajj under the caliph's patronage. This historical background also confirms a date for the composition of our letter between the death of Egypt's governor 'Abd al-'Azīz in $86 / 705$ and Sahl b. 'Abd al-'Azīz's move to Damascus in 99/717 to join his brother, caliph 'Umar II.

\section{Conclusion}

The papyrus letter discussed here takes us to the early Umayyad caliphate and the processes of formation of Islamic identity and statehood. The bajj to the "House" already mentioned in the Qur'ān is a duty for every individual Muslim who can undertake it. At the public level, it had considerable religious and political significance, bringing together large numbers of Muslims in one place at one time and conferring

\footnotetext{
${ }^{76}$ al-Kindī, Wulāt, 54.

77 Yu'affi āthār 'ammihi 'abd al-'azīz li-makānibi min wilāyat al-'ahd wa-'istibdala bi-'l-'ummāl 'ummālan wa-bi-'l-așhāb aș̣ā̄an (al-Kindī, Wulāt, 58. Cf. Ibn Taghrī Birdī, Nujūm, 1:210).

${ }^{78}$ EI2, “Umar (II)," 822.
}

upon the caliph, under whose tutelage it was conducted, powerful connotations of authority and credibility-factors that were even more significant in this early period, when the mechanics and meaning of the bajj were still evolving.

Internal textual evidence shows how this letter imposed a degree of control-or at least the attempt to exert control-from the capital over the periphery. Comparing our letter to contemporary, early Umayyad documents from Egypt confirms how unusual this is. Papyri found in Egypt contain very few references to places and people outside of Egypt and even less to the amir al-mu'minin. ${ }^{79}$ It is possible using the late first/seventh and early second/eighthcentury historical context to advance explanations for the extraordinary "presence" of the caliph in our Egyptian papyrus.

After the second civil war, which restored Umayyad control over the Muslim world but did not extinguish alternative ideas about authority in Islam, the caliph in Damascus was even more aware of the importance of keeping the announcement, organization and patronage of the yearly pilgrimage firmly in his own hands. Having members of Egypt's social and political élite, as representatives of the caliph's enemies of the past and his competitors of the present, join the caliph's pilgrimage was in this context of the utmost importance, and explains the urgent invitation conveyed in our letter. Sahl b. 'Abd al-'Azīz and 'Uqba b. Muslim would have been considered by the caliph in Damascus to have fallen into one or more of these categories of individuals in Egypt who absolutely had to be brought under the umbrella of the caliph's pilgrimage caravan. This concern is paralleled in a letter by 'Abd al-Hamīd b. Yahyā al-Kātib (d. 132/749) reporting (for a public audience, it seems) in detail the rituals of the hajj that the caliph Hishām performed in $106 / 725$. He was to be the last Umayyad caliph to have personally led the bajj. The letter shows the self-perceived importance of the involvement of the Umayyad caliphs with the pilgrimage (especially in the post-Zubayrid period). ${ }^{80}$

\footnotetext{
${ }^{79}$ For references to the caliph in the papyri, see the above commentary on line 7 . In these texts, the caliph appears as an absentee ruler in whose name orders and demands are issued. Seldom do we encounter the amīr al-mu'minin in a close and more or less direct relationship with Egyptian subjects as in our letter. Another first/ seventh-century papyrus mentions an Egyptian amīr who visits the amīr al-mu'minin and three government officials from al-Shām in Egypt on official business (Sijpesteijn, "Army Economics," 245-68).

${ }^{80}$ Ed. 'Abbās, 'Abd al-Hamìd ibn Yabyā, 205-206, no. 11.
} 
This does not mean, of course, that other motives might not have played a role in Sahl's and 'Uqba's decision to go on pilgrimage or not in the year the letter was written; nor that they did not fulfill other objectives by doing so.

The annual ritual of the bajj ties all Muslims together in a communal religious experience either at the House itself or as it was experienced from a distance. Participating or being associated with the rituals connects every Muslim via the generations that preceded him or her at Mecca with Abraham, the first believer said to have performed the hajj, and extends the tie to future visitors to the holy sites. ${ }^{81}$

Our sources indicate that the ceremonies of the bajj and even the location at which they were performed were not fixed in the earliest period of Islam. The bajj al-bayt was apparently undertaken under the early Umayyad caliphs to several holy sites at which circumambulation around a sacred stone was practiced. ${ }^{82}$ Inscriptions on the road to Mecca dating to the first decades of Islam indicate, however, that already from the earliest period, pilgrims travelled to

\footnotetext{
${ }^{81}$ See B. Anderson, Imagined Communities (London, 2nd ed., 1991), 54: "The Berber encountering the Malay before the Ka'ba must, as it were, ask himself: 'Why is this man doing what I am doing, uttering the same words that I am uttering, even though we can not talk to one another?' There is only one answer, once one has learnt it: "Because we are .. . Muslims."'

${ }^{82}$ See also the construction of the Dome of the Rock, where the central feature was the rock on which Ishmael-according to the Muslim tradition - had been sacrificed by his father Abraham (J. van Ess, "Abd al-Malik and the Dome of the Rock. An Analysis of Some Texts," in J. Raby and J. Johns, ed., Bayt al-Maqdis. 'Abd al-Malik's Jerusalem [Oxford, 1992], 1:89-104).
}

Mecca to perform the hajj. ${ }^{83}$ After the second fitna, when our papyrus was written, the importance of the pilgrimage to Mecca only increased, making it the most likely goal of our pilgrims Sahl and 'Uqba-a goal that was, moreover, so self-evident that it did not need any further explanation in the letter.

There is another reference in our letter that might take it in fact even closer to later legal prescriptions of the hajj. Sahl asks 'Uqba to pay for the hire of one camel, possibly referring to the later prescription that if a Muslim has the means and can pay for one riding animal ( $z \bar{a} d w a-r \bar{a} b i l a)$ for himself, he is obliged to undertake the pilgrimage, ${ }^{84}$ expressed so well in a prophetic hadith, "Whoever has the provision and the mount to carry him to the house of God and does not undertake the bajj, he might as well die a Jew or a Christian." 85

Our letter expresses a range of motives, from the political and public of the caliph and jurists, to the individual and private, which coincided to induce Sahl and 'Uqba to undertake the pilgrimage. Even if we will never be able to know exactly how these motives related to each other, it is clear that this papyrus offers us insights into the practice of Islamic prescriptions such as the hajj incomparable to any other contemporary or later source.

${ }^{83}$ An inscription dated 24/644-645 was found near modern Madā'in Ṣalih on the darb al-ḩajj. Although itself not referring to the pilgrimage, it is surrounded by first-century inscriptions that do ('A. al-Ghabbān, "Naqsh Zuhayr: Aqdam Naqsh Islāmī," Arabia 1 [2003], 293-342).

${ }^{84}$ Ibn Qudāma (d. 620/1223), al-Mughnī, ed. 'A. A. al-Turkī and 'A. F. al-Hulw (Cairo, 1987), 5:6-19.

${ }^{85}$ al-Tirmidhī (d. 279/892), Sunan, ed. 'I. 'U al-Da'ās (Hims, 1965-1968), Bāb al-ḅajj, no. 3. 